logos_i_ethos_2014_1_(36), s. 21-50

Błażej Baszczak

\title{
Cielesność i dekonstrukcja chrześcijaństwa: Jean-Luc Nancy a Jacques Derrida
}

Szczególnie w pracach La déclosion (Déconstruction du christianisme, 1) (2005), L'Adoration (Déconstruction du christianisme, 2) (2010), Corpus (1992) oraz Noli me tangere $(2003)^{1}$ Jean-Luc Nancy podjął się zadania dokonania tego, co sam nazywał „dekonstrukcją chrześcijaństwa”. Należy jednak zwrócić uwagę, że projekt ten jest przez filozofa nieustannie rozwijany, chociaż wydaje się, że pewne podstawowe zagadnienia zostały postawione przez niego już na sa-
Błażej Baszczak - absolwent filozofii i socjologii Uniwersytetu Zielonogórskiego. Tytuł doktora filozofii uzyskał na podstawie pracy: Dotykanie egzystencji. Jean-Luc Nancy'ego filozofia dekonstrukcji (2013). Autor książki o tożsamości narracyjnej w ujęciu Paula Ricoeura: Narracja i tożsamość. Paula Ricoeura hermeneutyka antropologiczna (2010). Zajmuje się współczesną filozofią francuską. mym początku, jak pytanie o status chrześcijaństwa w myśli filozoficznej Zachodu, problematyka wcielenia czy zmartwychwstania Chrystusa (relacja ciała do duszy)2, a konsekwentnie również kwestia samego

1 Refleksja Nancy’ego nad motywami chrześcijańskimi wzbudza spore zainteresowanie wśród wielu badaczy, czego jednoznacznym świadectwem jest książka omawiająca tylko tę problematykę: Retreating religion. Deconstructing christianity with Jean-Luc Nancy, eds. A. Alexandrova, I. Devisch, L. ten Kate, A. van Rooden, New York 2012.

2 Rozwijana przez Nancy’ego „dekonstrukcja chrześcijaństwa” może być rozumiana jako jedna z odmian tego, co nazywane jest we współczesnym dyskursie myślą postsekularną, czyli ponownym przemyśleniem określonych zagadnień religijnych i teologicznych $w$ ramach świeckiej filozofii. To odkrycie kategorii teologicznych w filozofii jest bardzo zróżnicowane, gdyż dotyczy między innymi zwrotu teologicznego w fenomenologii (Michel Henry, Jean Luc Marion) czy wykorzystywania figur i motywów teologicznych w tekstach Slavoja Žižka, Alaina Badiou i Giorgia Agambena. Motywy teologiczne, a szczególnie mesjanistyczne, pojawiły się także w pracach Derridy (kategoria sprawiedliwości, daru, przebaczenia, Innego). Zob. D. Janicaud, Le tournant théologique de la phénoménologie française, Combas 1991; P. Blond, Post-secular philosophy: Between philosophy and theology, London 1997, M. Warchala, Co to jest postsekularyzm? (subiektywna próba opisu), „Krytyka Polityczna”, 2007, nr 13. Na temat Nancy’ego „dekonstrukcji chrześcijań- 
statusu ciała. W dialog z refleksją Nancy’ego na ten temat wszedł jego bliski przyjaciel Jacques Derrida. I w tym artykule postaramy się najpierw przybliżyć tezy Nancy'ego, a następnie ich krytykę sformułowaną przez Derridę, aby na koniec spróbować podsumować ich dyskusję.

\section{Jean-Luc Nancy'ego projekt „dekonstrukcji chrześcijaństwa”}

To, co Nancy nazywał „dekonstrukcją chrześcijaństwa”, wiąże się $\mathrm{z}$ postawionym przez niego fundamentalnym pytaniem o rolę tradycji chrześcijańskiej w kształtowaniu zachodniej myśli filozoficznej już od przeszło dwóch tysięcy lat. Zagadnienie to Nancy traktował także jako polemikę z Derridą, który w eseju Przemoc i metafizyka, zawartym w zbiorze Pismo i różnica, rozważał wątki greckie i judaistyczne w kulturze Zachodu (do tych tez bezpośrednio odnosił się Nancy na początku eseju La déconstruction du christianisme wchodzącego w skład książki La déclosion). Derrida zapytywał tak:

Jesteśmy Grekami? Jesteśmy Żydami? Ale jacy my? Jesteśmy (pytanie nie chronologiczne, pytanie przed-logiczne) najpierw Żydami czy najpierw Grekami ? I czy ów dziwny dialog między Żydem a Grekiem, ów pokój jako taki, przybiera postać absolutnej spekulatywnej logiki Hegla, żywej logiki, doprowadzającej do zgody między formalną tautologią a empiryczną heterologią, a po przemyśleniu dyskursu proroczego w Przedmowie do Fenomenologii ducha? Czy też ów pokój przybiera,

stwa" jako odmiany myśli postsekularnej: Ch. Watkin, Difficult atheism: Post-theological thinking in Alain Badiou, Jean-Luc Nancy and Quentin Meillassoux, Edinburgh 2011.

W Polsce myśl postsekularną bada w swoich wielu pracach przede wszystkim Agata Bielik-Robson, która prowadzi Zespół do Badań nad Myślą Postsekularną w Instytucie Filozofii i Socjologii PAN. Zob. A. Bielik-Robson, „Na pustyni“ - kryptoteologie późnej nowoczesności, Kraków 2008; tejże, Erros. Mesjański witalizm i filozofia, Kraków 2012.

Natomiast w świecie anglosaskim jednym z największych badaczy myśli postsekularnej jest John Caputo. Jego najważniejsze prace na ten temat to: St. Paul among the philosophers (with L. Alcoff), Indiana University Press 2009; What would Jesus deconstruct?: The good news of postmodernism for the Church, Baker Academic 2007; The weakness of God: A Theology of the event, Indiana 2006; Questioning God: Religion and postmodernism II, co-eds. M. Dooley, M. Scanlon, Indiana 2001; The prayers and tears of Jacques Derrida: Religion without religion, Indiana 1997. 
na odwrót, postać nieskończonego odosobnienia i niedającej się pomyśleć ani wypowiedzieć transcendencji innego? Jakiż jest pokój, do którego horyzontu należy język stawiający owo pytanie? Skąd ten język czerpie siłę swego pytania? Czy można sporządzić obrachunek z owego historycznego sprzęgnięcia się judaizmu z hellenizmem? Jakąż ma prawomocność, jaki sens ów sprzęgający łącznik w tym stwierdzeniu, które spotykamy u najbardziej może heglowskiego z powieściopisarzy nowoczesnych: Jewgreek is greekjew. Extremes meet ${ }^{3}$.

„Grekożyd jest żydogrekiem. Krańcowości spotykają się" - to cytat z Jamesa Joyce’a, z jego powieści Ulisses ${ }^{4}$, na którą powoływał się Derrida, podsumowując swoje rozważania. Owe krańcowości to filozofia innego (myśl żydowska) i filozofia jako logos (myśl grecka).

Natomiast Nancy zapytywał, „czy ten «żydogrek», o którym mówi Derrida na końcu Przemocy i metafizyki (ten «żydogrek», który, jego zdaniem, konstytuuje naszą historię), nie jest po prostu chrześcijaninem. Można również zastanowić się, dlaczego nieustannie odwracamy nasz wzrok od chrześcijanina, tak jak gdybyśmy nie mogli popatrzeć bezpośrednio na chrześcijanina. Powiedzmy zatem [...], że chrześcijanin albo chrześcijaństwo jest rzeczą, która pozostaje do przemyślenia"5. Innymi słowy, co nowego wnosi myśl chrześcijańska, która zdominowała kulturę Zachodu, łącząc oba te motywy? Albo, jak twierdził Andrzej Nawrocki, podstawowym pytaniem Nancy’ego jest, „czy aby chrześcijaństwo nie składa się jedynie $z$ dwóch elementów, judaizmu i hellenizmu, i czy aby nie jest wyłącznie grą tych elementów?"6. W tym kontekście namysł Nancy’ego nad motywami chrześcijańskimi, zawarty $\mathrm{w}$ jego licznych pracach, należy interpretować jako pytanie usytuowane w szerokim kontekście filozoficznym, próbujące określić wyznaczniki kulturowe naszego, europejskiego myślenia. W tym sensie Nancy

3 J. Derrida, Przemoc i metafizyka. Szkic na temat myśli Emanuela Lévinasa, tłum. K. Kłosiński, [w:] tenże, Pismo i różnica, Warszawa 2004, s. 264-266.

4 J. Joyce, Ulisses, tłum. M. Słomczyński, Warszawa 1981, s. 533.

5 J.-L. Nancy, La déclosion (Déconstruction du christianisme, 1), Paris 2005, s. 204.

6 A. Nawrocki, O projekcie Jean-Luc Nancy’ego „dekonstrukcji chrześcijaństwa”, „Kwartalnik Filozoficzny", 2007, T. XXXV, s. 39. 
jednoznacznie podkreślał powiązania pomiędzy chrześcijaństwem i historią myśli zachodniej. Pisał tak, w formie założeń:

Chrześcijaństwo jest nierozerwalnie związane z Zachodem. [...] Dechrystianizacja nie jest pustym słowem, lecz [...] czymś, co nieustannie związane jest z licznymi aspektami Zachodu stanowiącymi unerwienie chrześcijaństwa. [...] Zachód w swej istocie, okcydentalizm, został zrealizowany poprzez wyeksponowanie szczególnego nerwu sensu. [...] Od tego momentu dekonstrukcja chrześcijaństwa towarzyszy Zachodowi aż do tej granicy?

Są to twierdzenia, które mają pokazać w szerokim kontekście filozoficzne i kulturowe powiązania chrześcijaństwa i kultury zachodniej. W wymiarze religijnym, teologicznym, świeckim czy filozoficznym tezy te wyznaczają przestrzeń i zadania dla współczesnego myślenia. Tym samym dla Nancy'ego chrześcijaństwo jako idea jest ważnym zadaniem intelektualnym, z którym warto się zmierzyć i które warto przemyśleć. Nie tyle badał on motywy żydowskie i greckie w chrześcijaństwie, co koncentrował się na ukazaniu rodzaju "gry” dokonywanej przez chrześcijaństwo dzięki istnieniu w jego łonie tych elementów. W tym sensie takie podejście bliskie jest samej istocie dekonstrukcji, która jest nieustanną pracą myśli, intelektualną inwencją, która w swojej pracy intelektualnej nie boi się łączyć nawet paradoksalnie sprzecznych motywów. Dlatego też Nancy twierdził, że chrześcijaństwo samo się dekonstruuje, tak samo jak najbardziej klasyczne pojęcia metafizyczne, gdyż, za sprawą wspomnianej „gry” elementów judaistycznych i greckich, nieustannie musi się definiować, dookreślać, zmieniać i odnawiać. Zawsze jest work in progress - wedle filozofa, dlatego pojęcia dekonstrukcja i chrześcijaństwo są ze sobą złączone. Jak pisał Christopher Watkin, zwrot „dekonstrukcja chrześcijaństwa” należy rozumieć w podwójnym sensie:

zarówno jako dekonstruowanie (metafizycznego) chrześcijaństwa oraz rozumienie samego chrześcijaństwa jako ruchu dekonstrukcji. Dekonstruowanie chrześcijaństwa 
jest uchwyceniem chrześcijańskiej samo-dekonstrukcji. Ale wtedy powstaje pytanie: jeśli dekonstrukcja jest częścią definicji chrześcijaństwa, czy istnieje cokolwiek poza chrześcijaństwem? Jeśli chrześcijaństwo jest zawsze samo-dekonstruowane, to czy jako samo-dekonstrukcja (jako szczególny rodzaj dekonstrukcji) jest wszędzie [...]?

Na ten wątek zwracała uwagę również Marie-Eve Morin, która zaznaczała:

Nancy mówi nie tylko, że struktura chrześcijaństwa sama się dekonstruuje, lecz że dekonstrukcja jest esencją chrześcijaństwa, że ruch dekonstrukcji jest ruchem chrześcijaństwa w swoim własnym działaniu przekraczania siebie. Jeśli chrześcijaństwo jest rozumiane jako dekonstrukcja, to nie jest możliwe zapytanie, jakie chrześcijaństwo jest samodekonstruowaniem. [...] Nancy’ego punkt widzenia jest taki, że ta struktura jest stale ruchoma, zwraca się przeciwko sobie, przekracza siebie, odwraca się od siebie?.

Nie chodzi tu o atakowanie czy bronienie dziedzictwa chrześcijaństwa, o jego gloryfikację czy deprecjonowanie, gdyż, jak twierdził Nancy, chrześcijaństwo jako takie jest w stanie nieustannego odnawiania się i autokorekty, które przynależą do jego głębokiej struktury i wewnętrznej logiki rozwoju. W tym sensie rosnąca sekularyzacja, dechrystianizacja kultury zapoczątkowana już w oświeceniu, albo coraz ważniejsza rola nauki w interpretacji świata i człowieka czy krytyka metafizycznych kategorii mogą być widziane jako część tego procesu znamiennego dla tradycji zachodniej, a tym samym również myśli chrześcijańskiej. Podobnie odrzucenie myślenia teleologicznego, eschatologii czy afirmacja „końca” historii, ideologii, metafizyki, a także, całkiem przeciwnie, współczesne ponowne zainteresowanie motywami religijnymi i teologicznymi na łonie filozofii (myśl postsekularna) przynależą, zdaniem Nancy’ego, do tego procesu i nie mogą być pomyślane

8 Ch. Watkin, Neither/Nor: Jean-Luc Nancy's deconstruction of christianity, „Research in Phenomenology", 2007, no. 37, s. 138.

M.-E. Morin, Jean-Luc Nancy, London 2012, s. 58. 
w oderwaniu od chrześcijaństwa, gdyż związane są z owymi, nieustannie się dotykającymi i separującymi, motywami żydowskimi i hellenistycznymi. W tym sensie „dekonstrukcja chrześcijaństwa” dokonuje się zarówno wewnątrz jego struktury, jak i poza nią. Zwracał na to uwagę Laurens ten Kate, pisząc że

dekonstrukcja chrześcijaństwa może zostać opisana jako konieczność radykalnej ambiwalencji wewnątrz chrześcijaństwa, wewnątrz jego historii, teologii, doktryny, rytuałów, sztuki: ambiwalencji poprzez którą chrześcijaństwo samo się dekonstruuje. Dlatego analizy dekonstrukcyjne chrześcijaństwa badają chrześcijańską autodekonstrukcję jako jej podstawową charakterystykę ${ }^{10}$.

Natomiast, jak pisał w innym artykule Laurens ten Kate, to co jest znamienną cechą dekonstrukcji chrześcijaństwa znajduje się i wewnątrz niego, i poza nim. „Dlatego dekonstrukcja chrześcijaństwa obejmuje skoncentrowanie się na dwóch strukturach refleksji: pierwszej, wewnątrz versus zewnątrz, oraz drugiej, byciu lub obecności versus stawaniu się" ${ }^{11}$. W tym znaczeniu „dekonstrukcja chrześcijaństwa” jest nieustannym procesem, gdyż samo chrześcijaństwo, zdaniem Nancy'ego, jest ciągłym zdarzeniem. W takim ujęciu „dekonstrukcja chrześcijaństwa” może być widziana jako konieczność stałej ambiwalencji wewnątrz chrześcijaństwa, wewnątrz jego historii, teologii, doktryny, rytuałów, sztuki, a poprzez połączenie go z kulturą Zachodu - w samej tej kulturze. Dla Nancy’ego „chrześcijaństwo nie oznacza niczego innego niż, esencjalnie, wymóg otwarcia tego świata na bezwarunkową inność i alienację" ${ }^{12}$. Ale to właśnie za sprawą tej ambiwalencji chrześcijaństwo samo się dekonstruuje, zmienia, odnawia

10 L. ten Kate, Intimate distance: rethinking the unthought God in christianity. On Jean-Luc Nancy's deconstruction of christianity, compared and confronted with the 'theological turn in phenomenology', ,Sophia”, 2008, vol. 47, issue 3, s. 340.

11 L. ten Kate, Outside in, inside out: Notes on the retreating God in Nancy's deconstruction of christianity, „Bijdragen. International Journal in Philosophy and Theology”, 2008, vol. 69, no. 3, s. 305-306.

12 J.-L. Nancy, La déclosion..., dz. cyt., s. 20. 
i transformuje. Chrześcijaństwo, jak i nasza europejska kultura, są dla Nancy’ego egzemplifikacją strukturalnej modalności najbardziej metafizycznych idei (teologicznych, filozoficznych, kulturowych). Nancy’ego dekonstrukcja chrześcijaństwa usytuowana jest na granicy naszej kulturowej, filozoficznej tradycji, którą sama nieustannie się określa, wyznaczając nowe modele myślenia. Nie chodzi tu o przechowanie za wszelką cenę w jednorodnej postaci tradycji chrześcijańskiej, ale o krytyczność w refleksji nad ograniczeniami i granicami naszego własnego myślenia.

W takim ujęciu projekt „dekonstrukcji chrześcijaństwa” obejmuje bardzo wiele różnych zagadnień. Nas najbardziej interesować będą te dotyczące problematyki ciała, które w teologii chrześcijańskiej Nancy rozpoznaje przede wszystkim w motywie relacji ciała do duszy. Konkretnie chodzi o problem inkarnacji (wcielenia) i zmartwychwstania ciała Chrystusa.

Zacznijmy od kategorii inkarnacji, która przez filozofa traktowana jest jako kluczowa w myśli chrześcijańskiej. Pisał on tak:

Wiemy dobrze, że serce teologii chrześcijańskiej jest ewidentnie konstytuowane przez chrystologię, że sercem chrystologii jest doktryna inkarnacji oraz że sercem doktryny inkarnacji jest doktryna homousia, współsubstancjalności i tożsamości albo współistotności pomiędzy Ojcem i Synem. I to jest nowe w chrześcijaństwie ${ }^{13}$.

Związek, zależność pomiędzy duchem i materią, duszą i ciałem, tym, co inteligibilne i zmysłowe znajdują w chrystologicznym pojęciu inkarnacji całkiem nowe ujęcie, niespotykane we wcześniejszych tradycjach intelektualnych, czyli w filozofii greckiej czy mesjanizmie judaistycznym. A jednocześnie jest ono tym, co musi zostać przemyślane w intelektualnym projekcie dekonstrukcji chrześcijaństwa, gdyż nie chodzi tu o odseparowanie ducha od ciała czy uprzywilejowanie jednej z tych kategorii na rzecz drugiej, czyli ustanowienie jakiejś hierarchii pomiędzy nimi. Chodzi o sposób, w jaki te pojęcia są faktycznie ujmowane 
we wzajemnej fuzji jako „współistnienie”, owa współsubstancjalność czy „wspólnota substancji”, jak to nazywał filozof.

W eseju Verbum caro factum („Słowo stało się ciałem”) Nancy rozważał chrześcijańską ideę wcielenia, inkarnacji, jako formułę, w której „Bóg czyni się człowiekiem”"14 i traktuje ją jako decydujący moment dekonstrukcji i samo-dekonstrukcji chrześcijaństwa. Innymi słowy Nancy poszukiwał takiego rozumienia wcielenia, w którym „ciało Chrystusa jest całkowicie inne niż ciało służące jako otoczka (albo więzienie, albo grób) dla duszy"15. To jest to, co nowe w myśli chrześcijańskiej, co wnosi ta tradycja do nowego ujęcia cielesności w relacji do tego, co niecielesne. W najogólniejszym sensie termin „«inkarnacja» najczęściej rozumiany jest bowiem w sensie wejścia w ciało jakiegoś bytu niecielesnego (ducha, Boga, idei); rzadziej w sensie przenikania jednej części ciała przez inną, albo przez obcą substancję [...]"16. Dlatego, zdaniem Nancy'ego, chrześcijańskie ujęcie inkarnacji nie rozróżnia pomiędzy ciałem a tym, co boskie. Ciało nie różni się od boskości, która porzuca swoją absolutną boskość po to, aby utożsamić się nie $z$ ludzkim istnieniem, ale jako ludzkie istnienie. W takim ujęciu ciało nie jest ,więzieniem duszy [...], ale rozciągłością, uprzestrzennieniem [...]. Ciało jest prawdą «duszy», która sama się ukrywa" ${ }^{\prime 7}$. Toteż, jak zaznaczał Joeri Schrijvers, dla Nancy’ego

chrześcijański Bóg jest zatem Bogiem, który alienuje swoją Boskość poprzez „przejście do zewnętrzności” oraz który nie jest niczym innym niż tą alienacją. Nancy jednoznacznie identyfikuje tutaj ruch Boskiej alienacji pochodzący z samej Boskości z generalnym aspektem swojej dekonstrukcji chrześcijaństwa, mianowicie z postępującym zniknięciem tego, co boskie, pozostawieniem nas tylko z ciałami, które są zgromadzone w świecie, zgromadzone (ale rozłączone) z sobą poprzez swoje połączenie ze wszystkimi innymi - pomiędzy bytami ${ }^{18}$.

$\begin{array}{ll}14 & \text { Tamże, s. } 125 . \\ 15 & \text { Tamże, s. } 127 . \\ 16 & \text { Tamże, s. } 125 . \\ 17 & \text { Tamże, s. } 127 . \\ 18 & \text { J. Schrijvers, What comes after christianity? Jean-Luc Nancy's deconstruction of christian- }\end{array}$ ity, „Research in Phenomenology”, 2009, no. 39, s. 278. 
Dlatego koncepcja inkarnacji może być interpretowana jako idea ostatecznego rozpłynięcia się Boga w świecie i Jego stanie się człowiekiem.

Wątek ten był także rozwijany w pracy Corpus, którą rozpoczyna eucharystyczna fraza „To jest ciało moje”, podana przez filozofa w języku łacińskim jako „Hoc est enim corpus meum”. Wokół tego zdania krąży jeden z ważniejszych aspektów myślenia Nancy’ego dotyczący cielesności. Filozof rozpoznawał w tej frazie element, który odróżnia naszą kulturę od innych. Jest to obsesja

wskazywania na to oto oraz przekonywania (innych, a także nas samych), że to oto, tutaj właśnie, jest tym, co nie daje się zobaczyć ani dotknąć [...] ani tutaj, ani nigdzie indziej. Że to oto nie jest tym, czym jest w obojętne jaki sposób, lecz jest ciałem - istnieje jako ciało jego. Oto myśl, od której nie możemy się uwolnić: jego ciało (wszystko jedno, czy chodzi tu o Boga czy Absolut). I z uporem trwamy, że to ma ciało albo jest ciałem (można by więc pomyśleć, że to jest ciałem - w ogóle i absolutnie $)^{19}$.

W tym uczynieniu obecnym czegoś nieobecnego, wcieleniu czegoś, co jest bez ciała, zdaniem Nancy'ego, wyraża się podstawowy paradygmat kultury chrześcijańskiej, który w istocie nie jest ani teologiczny, ani świecki. Paradygmat ten powiada, że świat zjawisk jest całkowicie obecny, tu i teraz. A dokładniej umieszcza zjawisko w jedności tego, co zmysłowe i inteligibilne, cielesne i idealne jednocześnie. W tym filozoficznym odczytaniu eucharystycznej frazy „Hoc est enim corpus meum” dążył Nancy do wydobycia, jego zdaniem, fundamentalnej ambiwalencji zawartej w kulturze chrześcijańskiej, a odnoszącej się do samego ciała Chrystusa. Z jednej strony, podczas każdej mszy eucharystycznej chodzi o pragnienie widzenia, dotykania, zjedzenia, czyli uczestnictwa w ciele Chrystusa, a nawet w pewnym sensie bycie ciałem Chrystusa, ale $\mathrm{z}$ drugiej strony - mamy do czynienia z niewidzialnym, niematerialnym, nieobecnym Świętym Ciałem. Jak pisał Nancy: 
Ciało własne, ciało obce: hoc est enim wskazuje, czyni dotykalnym oraz każe nam spożywać właśnie to ciało własne. Własne ciało, czyli Własność samą w sobie, ucieleśnione Bycie-ku-sobie. W tym samym momencie - i za każdym razem - okazuje się ono jednak ciałem obcym, które staje się widoczne, choć jednocześnie niemożliwe do przełknięcia w tej swojej monstrualności. Z sytuacji tej nie ma wyjścia, bo już jesteśmy wplątani w galimatias obrazów, oscylujący między wizerunkami Chrystusa zamyślonego nad opłatkiem i Chrystusa ofiarowującego swoje rozedrgane i skrwawione Najświętsze Serce ${ }^{20}$.

To, co zaświadcza o duchowej, absolutnej obecności, w rzeczywistości oznacza obecność, która jest jednocześnie nieobecnością, bliskością, która implikuje dystans, dotykiem, z którego wynika nieskończona separacja. Jak zaznaczała Morin: „Ciało nie jest ani więzieniem duszy, ani doświadczeniem ukrytego wewnętrz, ani nie jest pełną obecnością: jest otwartą i przerwaną obecnością, ekstensją albo uprzestrzennieniem, «miejscem» egzystencji, zdarzeniem sensu" ${ }^{21}$. Niezależnie od zasadności Nancy'ego interpretacji eucharystycznej frazy oraz miejsca, jakie nadał jej w zróżnicowanej tradycji kultury chrześcijańskiej, problem, który podejmuje, wyraża się w próbie ponownego usytuowania wewnętrznej logiki wcielenia, leżącej, zdaniem filozofa, w samym sercu biblijnej narracji Nowego Testamentu. Ciało Chrystusa jest duchem, który ustanawia cielesność i które konstytuuje chrześcijaństwo.

W Eucharystii my nie uczestniczymy albo nie dotykamy Ducha, który mógłby zostać uobecniony przez opłatek [...]. Bóg uobecniający się w świecie jako ciało (albo jako opłatek) nie oznacza, że Absolut wchodzi w świat, albo że Idea sama materializuje się tak, że możemy ją odczuwać albo dotykać. To znaczy tylko, że to, co Niedotykalne, jest „tu i teraz” i nie jest ukryte poza. To jest, tu i teraz, to inne ciało, to znaczy, nie materialne ciało, ale ciało sensu, ciało, które otwiera się na sens ${ }^{22}$. 
Wcielenie, zdaniem Nancy’ego, jest nie tyle momentem złączenia, uobecnienia czy partycypacji ciała oraz ducha, który następnie jest powtarzany przez masy, ile jest zetknięciem, stycznością oraz separacją i dystansem jednocześnie. Jest dotknięciem niedotykalnego, nienamacalnego, czegoś w istocie nieuchwytnego.

W innej pracy Nancy’ego, której tezy teraz omówimy - Noli me tangere - ten chrystologiczny wymiar dotyku i samej cielesności został jeszcze bardziej zasygnalizowany poprzez powiązanie go z problematyką zmartwychwstania Chrystusa. Ta niewielka rozprawka jest złożonym namysłem nad pojedynczą sceną z Ewangelii św. Jana, gdzie zmartwychwstały z grobu Chrystus pojawia się przed Marią Magdaleną i ona, na początku nie rozpoznając Go, stara się Go dotknąć, a wtedy On jej powiada: „Nie dotykaj mnie“. To znaczy tytuł tej książki w języku łacińskim. Zakaz dotyku, który Chrystus adresował do Marii Magdaleny, może w pierwszej intuicji sugerować, że to, co święte w chrześcijaństwie: Święte Ciało, Hostia, jest otoczone przez tabu; nałożony został na nie zakaz dotyku. W tym sensie chrześcijaństwo może jawić się jako religia niedotykalności, separacji pomiędzy ciałem ludzkim, czyli upadłym, którego historia zaczęła się od grzechu Adama i Ewy, a świętym Ciałem Chrystusa. Jednak, jak twierdził Nancy, nie jest tak, że jeśli Ciało Boga dane jest do „zjedzenia” i „wypicia” (czyli dotknięcia w najbardziej bezpośredni z możliwych sposobów) w Komunii Świętej, to nie ma tu już niczego niedotykalnego. W rzeczywistości Komunia, zarówno jako reprezentacja symboliczna, jak i partycypacja w poświęcającym się dla innych Ciele Bożym, czyni z chrześcijaństwa religię dotyku i kontaktu par excellence. Pisał tak: „Chrześcijaństwo pozostanie wynalazcą religii dotyku, zmysłowości, bezpośredniej obecności w ciele i sercu”23. Jest to powtórzenie Nancy'ego interpretacji eucharystycznego zdania z początków książki Corpus - „To jest ciało moje“ („Hoc est enim corpus meum”) - zdania, które w swej istocie świadczy o tym, że chrześcijaństwo jest religią współsubstancjalności ciała i ducha. Namysł filozofa nad zmartwychwstaniem Chrystusa i interpretacja dotyku, zawarte 
w Noli me tangere trochę z innej strony, pokazują ten motyw współsubstancjalności jako nigdy niedokonany do końca, wiecznie niespełniony, dynamizujący relację ciała i ducha. Dla Nancy’ego scena z Ewangelii św. Jana, gdy zmartwychwstały Chrystus ukazuje się Marii Magdalenie, jest momentem pomiędzy życiem a śmiercią, pomiędzy tym, co dotykalne, a niedotykalne.

Nancy'ego interesował ten niepewny status zmartwychwstałego ciała Chrystusa. Jak twierdził, nie jest to ciało „zregenerowane” czy „ożywione", ani nie jest czymś narodzonym na nowo, ponownie ożywionym czy wcielonym. To jest ciało martwe, choć żywe, żyjące, odchodzące do zaświatów, choć jeszcze pozostające w naszej rzeczywistości, takie samo jak przed śmiercią, choć zarazem zupełnie inne. Morin zaznaczała, że słowo „zmartwychwstanie” (rezurekcja) pochodzi z greckiego słowa anastasis, które dosłownie znaczy „powstawać”. Natomiast łacińskie słowo resurgere oznacza „zmartwychwstanie”. Dlatego „Nancy chce rozróżnić pomiędzy dwoma sensami kategorii rezurekcji, jednym, który implikuje ruch od horyzontalnego do wertykalnego ciała, [...] oraz drugim, który zakłada reanimację ciała, które zyskuje nowe życie" ${ }^{24}$. Jak pisał Nancy, „to nie jest drugie życie, to jest erekcja (albo regeneracja), poprzez którą horyzontalny przebieg życia obraca się w wertykalny sygnał"25. Dlatego nieśmiertelność nie jest inną stroną śmierci, w innym życiu, lecz istnieje w samej śmierci. I dalej wskazywał: „W śmierci ostateczne zawieszenie sensu (egzystencji) krystalizuje wieczną jasność zawieszonego sensu"26. W tym sensie zmartwychwstanie Chrystusa można ujmować jako nieskończone przedłużanie, przeciąganie śmierci w życiu, przez co nie pozwala to na jednoznaczne usytuowanie życia i śmierci, a szerzej - obecności i nieobecności tego co żyje i co jest martwe, a w końcu ciała i duszy jako takich. W tym momencie niejednoznacznej identyfikacji i nieskończonego przenikania tych wielu opozycji stają się one nieodróżnialne. Z jednej strony Święte Ciało, Ciało Wniebowstąpienia,

24 M.-E. Morin, Jean-Luc Nancy, dz. cyt., s. 68.

25 J.-L. Nancy, L'Adoration (Déconstruction du christianisme, 2), Paris 2010, s. 78.

26 Tamże, s. 45. 
a z drugiej strony - ciało śmiertelne, ,jedno jest wydobywane przez drugie, to drugie jest śmiercią pierwszego" ${ }^{27}$. Ciało zmartwychwstałe stało się dla Nancy’ego kategorią, poprzez którą zasada tożsamości i identyczności została przerwana. Ten moment przerwania opisuje struktura dotyku i separacji wyrażona w tytularnym zakazie „noli me tangere” - nie dotykaj mnie. Widziana w ten sposób relacja pomiędzy ciałem a duchem jest odmienna od omawianej wcześniej zasady ich współsubstancjalności wyrażonej w formule „Hoc est enim corpus meum”. Tutaj ma wymiar dynamiczny, w istocie swojej niedokonany. Według Nancy’ego zmartwychwstałe ciało Chrystusa

jest dotykalne. Ale nie jest tak, że ono nam się prezentuje. Raczej odrzuca kontakt. Jego bycie i prawda jako zmartwychwstałego są zawarte w tym odrzuceniu, w tym wycofaniu, które pozwala dać miarę dotykowi, o który powinno chodzić: nie dotykając ciała, dotykać swojej wieczności. Nie przechodząc w kontakt ze swoją uobecnioną manifestacją, dołączając do swojej realnej obecności, która polega na jej odejściu ${ }^{28}$.

Dlatego, zdaniem Nancy'ego, w tym zmartwychwstałym ciele Chrystusa nie wyraża się separacja ciała i ducha ani ich fuzja, czyli złączenie w ucieleśnieniu tego, co duchowe. Zarówno „upadła”, ziemska cielesność, jak i cielesność święta są wpisane w ten niezdeterminowany status zmartwychwstałego ciała Chrystusa. W takim ujęciu „chrześcijaństwo nie jest ani myślą o separacji ciała i ducha, ani o ich połączeniu, ale raczej o rozumieniu ciała (le chair) jako kontakcie-separacji pomiędzy nimi. Ciało jest esencjonalnie ambiwalentne: zarówno upadłe, śmiertelne ciało i święte ciało, zmartwychwstałe ciało" ${ }^{29}$. Dlatego, według filozofa, w dotyku i jednoczesnej separacji ducha i ciała wyłania się kwestia rzeczywistej ich ambiwalencji. Dla Nancy’ego duch i ciało 
istnieją w dotyku, który występuje jako dotyk odrzucający, odmawiający zawłaszczającego dotykania.

Próba przemyślenia i interpretacji współsubstancjalności, czy wręcz identyczności ducha i materii, która wedle Nancy’ego ma leżeć w samym sercu myśli chrześcijańskiej (zarówno w odniesieniu do kategorii inkarnacji, jak i zmartwychwstania Chrystusa), rozwijana była również w dziele L'Extension de l'âme analizującym problematykę relacji ciała i duszy w refleksji Kartezjusza.

Przypomnijmy, że autor Medytacji o pierwszej filozofii zakładał ontologiczny dualizm, czyli istnienie dwóch odrębnych substancji - ciała (res extensa, czyli rzecz rozciągła) i duszy (res cogitans, czyli rzecz myśląca), które zasadniczo się różnią. Co prawda, Kartezjusz zakładał oddziaływanie pomiędzy nimi, ale miał problem ze stworzeniem jasnej teorii tego dowodzącej. W takim ujęciu w człowieku istnieją dwie odrębne substancje, które, jak pisał Nancy, należy „wyobrazić sobie raz jako jedną, jednostkową rzecz, a drugi raz jako dwie rzeczy, które są wewnętrznie sprzeczne" ${ }^{\text {"30. }}$. Wedle Nancy'ego jedynym sposobem uniknięcia tej aporii, tej paradoksalnej jedności było przyznanie, że nie tylko ciało jest rozciągłe, lecz również dusza ma taką właściwość. Jak sam to ujmował:

Ciało rozpoznaje siebie, o ile jest duszą lub o ile jest ostatecznie połączone $z$ nią. Ale dusza rozpoznaje siebie w ten sposób jako rozciągłą nie poprzez ciało, lecz zgodnie z rozciągłością ciała. To jest konieczne do rozpoznania rozciągłości duszy, która jest zmieszana z wszelką rozciągłością ciała bez dzielenia jej na tę o charakterze nieprzeniknionym i wykluczania rozciągłości miejsc ${ }^{31}$.

Nancy zaproponował takie odczytanie Kartezjusza, w którym ciało i dusza są połączone, ale nie jako coś zawartego w jakimś „naczyniu” czy, jak proponował sam autor Rozprawy o metodzie - w szyszynce. To nie złączenie elementu rządzącego i podległego, lecz raczej obopólna rozciągłość rzeczy oraz czegoś, co zasadniczo uznawane było za 
nierozciągłe (czyli res cogitans w filozofii Kartezjusza, co nazywał on również duszą). Tym samym również ciało jako $z$ definicji rozciągłe (res extensa) nabiera wymiaru nierozciągłego w tym połączeniu $\mathrm{z}$ tradycyjnie niematerialną, nierozciągłą duszą. W tej fuzji dusza rozumiana jest jako zdolność świadomości czy wiedzy o tym, co rozciągłe; sama musi mieć fizyczny wymiar poprzez ciało, które rozpoznaje i „informuje”, z którym wchodzi w relacje. Jak zaznaczała Antonina Birnbaum:

Kartezjusz rozwija dwa rodzaje oczywistości, każdy korespondujący z dwiema kwestiami zawartymi w duszy - z faktem, że ona myśli i z faktem, że ona działa i doznaje bólu - każdy pochodzący ze specyficznej relacji z zewnętrznością. Albo dusza jest dotkniętą przez samą siebie w zwątpieniu, albo dusza jest połączona $\mathrm{z}$ ciałem w codziennym życiu. Ale za każdym razem chodzi o to, że sobość odnajduje siebie usytuowaną „poza sobą" $[\ldots]^{32}$.

Dlatego, z jednej strony, ciało ukazuje się jako rozciągłość materii, jako to, co jest rozpoznawane w rozciągłości duszy, ale również, jako materia, jest w pewien sposób nieprzeniknione, niedostępne, niezgłębione właśnie dzięki kontaktowi z duszą. Toteż, z drugiej strony, sam Kartezjusz dostarczał określeń, dzięki którym Nancy opisywał ciało nie jako rzecz, lecz jako to, co doświadcza relacji przestrzennych, uczuć i wrażeń, widzenia, dotyku, przyjemności i bólu itd. Jak pisał Nancy:

Dusza może zostać dotknięta przez ciało, a ciało przez duszę. Jedno przez drugie; tym jest dotyk: kontaktem, który komunikuje, pozostawiając nienaruszone każde z dwóch res (res extensa i res cogitans). Dotyk, według Kartezjusza, zawsze dotyka tego, co nieprzeniknione. [...]. W punkcie, gdzie się dotykają, duch i ciało są nieprzeniknione jedno wobec drugiego, a przez to połączone. Dotyk wprowadza kontakt wobec dwóch rzeczy nienaruszonych ${ }^{33}$.

32 A. Birnbaum, To Exist is to exit the point, [w:] J.-L. Nancy, Corpus, tłum. R. A. Rand, New York 2008, s. 147.

33 J.-L. Nancy, Corpus, dz. cyt., s. 80-81. 
Takie odczytanie Kartezjusza było dla Nancy’ego pretekstem do rozważań nad jego własną koncepcją dotyku, a zarazem ograniczeń tej kategorii. Według Nancy'ego materia jest nieprzenikniona w swojej rozciągłości, jest zawsze zewnętrzna wobec fenomenalnego świata zjawisk. W takim sensie Birnbaum zaznaczała, że „duchowość konstytuuje wewnętrzną esencję wszelkiego zmysłowego świata $\mathrm{w}$ jego zewnętrznych manifestacjach. Albo ujmując to bardziej precyzyjnie: materialność jest tylko ekspresją relacji umysłu do siebie samego" ${ }^{34}$. I dalej twierdziła:

Albo dusza jest samodotknięciem siebie, niematerialną substancją poza rozciągłością [...] wszelką zewnętrznością rzeczy, która jest najbardziej zewnętrzna. Albo dusza przenosi siebie do swojej jedności z ciałem i przestaje być relacją do siebie, staje się samą ekspozycją w połączeniu z cielesną zewnętrznością i w ten sposób eksponuje się wobec innych, uobecnia się na świat, na „bycie świata”35.

Ta relacja pomiędzy materialnością a duchowością, rozciągłością a nierozciągłością zachodzi poprzez dotyk, czyli styczność, w którym dwie formy rozciągłości - sens i materia - są wyeksponowane wobec siebie nawzajem. Egzystencja, a właściwie to, co Nancy za Heideggerem nazywał „ex-zystencją", to ciało ujmowane jako ekstensja duszy (jako sens) oraz dotykanie sensu poprzez rozciągłość tego, co niedotykalne (jako cielesna materia). Nancy tak o tym pisał: „Ciało jest ekstensją duszy aż do ekstremum świata i do kresów samego siebie, każdy uwikłany jest $\mathrm{w}$ innego oraz niewyraźnie odróżniony, rozciągły, sięgający do punktu zerwania" ${ }^{36}$. Nancy wprowadził kategorię dotyku, podkreślając dystans i zarazem kontakt w relacji do sensu i materii, który eksponuje i ujawnia świat nie jako jednoczesną współsubstancjalność ducha i materii, lecz w dialektyce ich jednoczesnego odłączania i łączenia. Podsumowując ten wątek, Morin pisała tak:

\footnotetext{
34 A. Birnbaum, To Exist is to exit the point, dz. cyt., s. 146.

35 Tamże, s. 149.

36 J.-L. Nancy, Corpus, dz. cyt., s. 83.
} 
Substancjalna obecność [...] jest negacją obecności-ku-sobie; to jest punkt poza rozciągłością. To, że jestem rozciągły, oznacza, że jestem wyeksponowany na (siebie lub innych). Dzięki tej zewnętrzności istnieję, odczuwam siebie egzystującego. Ale odtąd nie istnieje egzystencja, która nie odczuwa, nie ma egzystencji (nie ma „ego Cogito”), która nie jest „rozciągła ${ }^{37}$.

Psyche jest rozciągła, pisał Nancy w dziele Corpus ${ }^{38}$. Dlatego nie istnieje opozycja pomiędzy ciałem a duszą. Dusza jest obecnością ciała, jego bycia na zewnątrz-siebie. Sama dusza jest rozciągła zdaniem Nancy’ego, co potwierdza tylko rozpoznane wcześniej przez niego motywy świadczące o współsubstancjalności duszy i ciała w teologii chrześcijańskiej. W takim ujęciu dusza nie jest podporządkowana ciału; ono się z nią jednoczy jako z czymś tylko pozornie sobie obcym.

Podsumowując ten wątek rozważań, można zauważyć, że refleksja Nancy'ego na temat tekstu Kartezjusza i jego komentarze do tez chrześcijańskich być może pozwalają teraz na lepsze rozjaśnienie dość trudnych i złożonych motywów zawartych we wcześniej napisanej pracy Corpus. Dzieło to jest swoistym połączeniem motywów teologicznych, typowo chrześcijańskich, z tezami filozoficznymi w ten sposób, że jedne są dekonstruowane przez drugie. Poprzez taką strategię uwidacznia się charakterystyczny dla Nancy’ego sposób ujmowania cielesności, a także jego własne spojrzenie na filozofię chrześcijańską, którą interpretował w dość nowatorski sposób. Widać to w opisywaniu relacji duszy/ducha do ciała. W Corpus rozważany był wzajemny związek pomiędzy nimi:

Dusza jest formą ciała, a zatem ciałem (rozciągnięta psyche). [...] Duch jest (w) zniesieniem, sublimacją, wysubtelnieniem wszelkiej formy ciał - rozciągłości, materialnego podziału - przejściem w wydestylowaną i wzniosłą istotę sensu ciała. Duch jest ciałem sensu, czyli sensem ucieleśnionym. Duch jest organem sensu, czyli cia-

37 M.-E. Morin, Jean-Luc Nancy, dz. cyt., s. 127.

38 J.-L. Nancy, Corpus, dz. cyt., s. 85. 
łem prawdziwym, Ciałem Przemienionym. Duch chrześcijaństwa, to znaczy chrześcijaństwo w postaci teologii Ducha Świętego, zawiera się tu bez reszty ${ }^{39}$.

Chrześcijańskie pojęcie ducha, jako rodzaj transcendencji ciała, zdaniem Nancy'ego zakorzenione jest w ciele sensu. Jego ujęcie jako ducha możliwe jest tylko jako materialne ciało sensu, ani transcendentne, ani immanentne, lecz jako kontakt, styczność w separacji do skończonego sensu i nieprzeniknionej materii.

Na koniec należy zwrócić uwagę, że Nancy, używając kluczowych pojęć filozofii chrześcijańskiej - eucharystia, wcielenie, zmartwychwstanie, współsubstancjalność ciała i ducha - nie tyle starał się wyeksponować chrześcijańską ontologię, ile pewne jej egzystencjalne podłoże, które jednak nie jest żadną immanentną tożsamością czy jednorodną substancją, a właściwie w ogóle nie jest czymś trwałym, lecz raczej nieskończonym otwarciem świata w jego nieustającej ekspozycji ucieleśnionego sensu. Jak pisał Schrijvers:

Refleksja Nancy’ego jest tym, co można by nazwać „egzystencjalną” albo nawet etyczną wersją Derridowskiej różni. Nancy wyobrażał sobie zdarzenie świata (i bycia) jako pojawienie się tego, co nieoczekiwane i co przekracza nasze antycypacje i reprezentacje. W pewien sposób, można powiedzieć, my musimy stać się tą różnicą pomiędzy sensem i znaczeniem, odkąd sens jest dokładnie samym wycofaniem się znaczenia - wycofaniem się pełnej obecności ${ }^{40}$.

To jest refleksja, w której ciało jest zdarzeniem sensu, poprzez które istnieje wszystko, co się pojawia. Ciało jest więc światem, jego stronami, miejscami, przestrzeniami, jego ekspozycją. Jak pisał filozof: „Ciała są ekspozycją Boga i nie istnieje żadna inna jego ekspozycja. [...] Oznacza to, że nie ma Boga ani bogów. Są tylko miejsca. Miejsca - są boskie, ponieważ uwolnione od Ciała Boga oraz Śmierci we Własnej Osobie.

39 Tamże, s. 69.

40 J.Schrijvers, What comes after christianity? Jean-Luc Nancy's deconstruction of christianity, dz. cyt., s. 272. 
Są boskie za sprawą otwarcia, poprzez które wszystka «boskość» zapada się i ulega skurczeniu, pozostawiając obnażony świat naszych ciał. Miejsca obnażenia, miejsca ubóstwa, miejsca limon terrae" ${ }^{41}$. Takie myślenie o ciele, duszy i Bogu (i ich wzajemnej relacji) uwidacznia wykonywaną przez Nancy’ego pracę „dekonstrukcji chrześcijaństwa”, która każe każdej z tych kategorii dekonstruować się, ulegać „grze” swoich elementów, ale nie po to, aby dokonać ich destrukcji ani też rekonstrukcji, lecz pokazać ich modalność, przechodniość, współsubstancjalność. Jak zaznaczał Roberto Esposito:

Dekonstrukcja jest esencją chrześcijańskiej procedury, przynajmniej jeśli chrześcijaństwo nie jest interpretowane jako doktryna wiary, ale raczej jako otwarcie punktu naszej historii, albo raczej ścisłej idei historii [...]. Dekonstrukcja chrześcijaństwa nie może zatem mieć innego sensu niż zlokalizowanie i interpretacja tego źródłowego elementu, tego płonącego rdzenia, tego przebłysku sensu, który wszystko inne czyni możliwym $[\ldots]^{42}$.

W takim ujęciu, chrześcijaństwo, jako metafizyczny rdzeń kultury zachodniej, wedle Nancy'ego, ulegając nieustającej pracy dekonstrukcji, dekonstruuje również tę kulturę, i to jest stawką w refleksji filozofa.

\section{Jacquesa Derridy krytyka Jean-Luc Nancy'ego haptocentrycznej metafizyki ${ }^{43}$}

Jednym z tych, którzy w największym stopniu docenili Nancy’ego refleksję o cielesności i zarazem byli jej wnikliwymi krytykami, był Derrida

${ }^{41} \quad$ J.-L. Nancy, Corpus, dz. cyt., s. 56.

42 R. Esposito, Flesh and body in the deconstruction of christianity, „Minnesota Review”, 2010, no. 75 , s. 92.

43 Zgodnie z greckim źródłosłowem haptein oznacza dotykać. Derrida w swoim komentarzu myśli Nancy’ego (Le Toucher. Jean-Luc Nancy) postawił tezę o zdominowaniu zachodniej filozofii przez określony sposób ujmowania dotyku oraz samej cielesności jako czegoś homogenicznego, ujednoliconego. Tym samym określał tę tradycję jako haptologię lub „metafizykę haptocentryczną", podobnie jak wcześniej stosował pojęcia logocetryzmu lub fonocetryzmu, by ukazać dominację w historii filozofii pojęć logosu i głosu. 
w swojej książce Le Toucher. Jean-Luc Nancy. Główną tezą autora w jego komentarzu myśli Nancy’ego było podkreślenie faktu zdominowania właściwie całej tradycji filozofii europejskiej przez kategorię dotyku ujmowaną jako połączenie, zetknięcie, styczność, co, jego zdaniem, ma miejsce również w filozofii Nancy’ego. Derrida tę tradycję, w której kategoria dotyku gra ważną rolę, nazwał intrygą filozoficzną, „przebiegającą przez granice myśli europejskiej, które oddzielają niemiecki idealizm od francuskiej tradycji racjonalizmu, europejską myśl kontynentalną od empiryzmu brytyjskiego" ${ }^{44}$. Jego zdaniem tym, co integruje te odległe od siebie postawy filozoficzne, jest myślenie o ciele jako autonomicznej własności oraz indywidualnej integralności. Podejście takie ma swoje korzenie w myśli chrześcijańskiej, w chrześcijańskiej koncepcji inkarnacji (wcielenia), gdzie duch staje się ciałem, co najbardziej klarownie wyłożone zostało w doktrynie ciała Chrystusa. To jest dziedzictwo, które Nancy również wykorzystywał w swoim projekcie „dekonstrukcji chrześcijaństwa”, o czym pisaliśmy wyżej. W tym sensie Derridy interpretacja filozofii ciała jest wyeksponowaniem teologicznych podstaw tego typu rozważań $\mathrm{w}$ historii filozofii oraz próbą ich skonfrontowania $\mathrm{z}$ filozofią ciała Nancy’ego. Dlatego w celu uzyskania szerszego kontekstu rozważań są w rozprawie Derridy przywoływani inni myśliciele, których refleksja, za każdym razem w odmienny sposób, również była zogniskowana na kategorii ciała, a mianowicie Marie-François-Pierre-Gonthier Maine de Biran, Edmund Husserl, Emmanuel Lévinas oraz Maurice Merleau-Ponty. W swojej książce Le Toucher Morin twierdziła:

Derrida zwracał swoją uwagę na pewien aspekt tej tradycji, który nazywał „haptologicznym" (w języku greckim haptein oznacza dotykać). Ta tradycja ma udział w takim geście metafizycznym, o ile ujmuje ona dotyk w kategoriach identyczności, homogeniczności, bezpośredniości i samo-obecności, nawet kiedy podkreśla pewne przerwanie albo dystans ${ }^{45}$.

44 I. James, The fragmentary demand - an introduction to the philosophy of Jean-Luc Nancy, Stanford 2006, s. 119.

45 M.-E. Morin, Jean-Luc Nancy, dz. cyt., s. 65. 
Dlatego Derrida, wykorzystując kategorię dotyku, starał się pokazać, że jest ona tylko nowym, innym sposobem przyłączenia się do tradycji myślenia zdominowanej przez metafizykę obecności, która uprzywilejowuje tożsamość zamiast inności, homogeniczność zamiast heterogeniczności, bezpośredniość zamiast separacji lub dystansu.

Zagadnieniem, na którym przede wszystkim koncentrował się Derrida, odnosząc się bezpośrednio do filozofii Nancy’ego, był dotyk. Wokół tej kategorii, zdaniem twórcy dekonstrukcji, zogniskowane jest całe myślenie Nancy’ego. Jest to figura posiadająca szczególne miejsce w jego refleksji, gdyż jest punktem pomiędzy ciałem czy materialnością cielesności a tym, co w tradycji filozoficznej zwykło nazywać się duszą, umysłem, myśleniem itd. Jest to również kategoria filozoficzna, którą Nancy rozwijał po to, aby, zdaniem Derridy, „odeprzeć, pod nazwą dotyku, wszelki idealizm i wszelki subiektywizm, czy to transcendentalny, czy psychoanalityczny" ${ }^{46}$. To pozwoliło Derridzie na postawienie wyjściowej tezy dotyczącej filozofii Nancy'ego. Pisał tak:

Dotyk pozostaje dla Nancy'ego motywem ujmowanym jako rodzaj absolutnego realizmu, irredentystycznego ${ }^{47}$ i post-dekonstrukcyjnego. Przestrzenność przestrzeni, która jest wystawiona na dotyk, pozostaje nieredukowalna do żadnej matematycznej rozciągłości, a być może w ogóle do żadnej wiedzy. Absolutny realizm, ale nieredukowalny do żadnej tradycyjnej formy realizmu ${ }^{48}$.

Innymi słowy, zdaniem Derridy, z jednej strony realizm Nancy'ego, jako post-dekontrukcyjny, jest nieredukowalny do żadnego innego tradycyjnego realizmu, to znaczy nieredukowalny do żadnej tradycyjnej

46 J. Derrida, Le Toucher. Jean-Luc Nancy, Paris 2000, s. 16.

47 Irredentyzm to ideologia polityczna dążąca do połączenia w jeden organizm państwowy ziem zamieszkiwanych przez podobne grupy etniczne, która ma swoje korzenie w dziewiętnastowiecznym nacjonalizmie włoskim. Derridzie natomiast chodziło o kwestię granic lub ograniczeń, doktrynę, która wymaga włączenia tego, co leży bezpośrednio poza granicami, lecz niejako znajduje się w ich orbicie wpływów czy zainteresowań. Zob. I. James, The fragmentary demand..., dz. cyt., s. 118.

48 J. Derrida, Le Toucher. Jean-Luc Nancy, dz. cyt., s. 60. 
logiki reprezentacji lub metafizyki obecności, którą, rzecz jasna, odrzuciłby Derrida, przy okazji jawnie krytykując filozofię Nancy’ego. Ale $\mathrm{w}$ takim razie, $\mathrm{z}$ drugiej strony, dlaczego w swoim komentarzu zastosował pojęcie irredentyzmu? Kryje się w tym pewna ambiwalencja. Jak twierdził Ian James:

Może oznaczać to sugerowaną przez niego pewną tendencję w myśli Nancy’ego do asymilacji, przywłaszczenia, opanowania czy przezwyciężenia ukazywanych przez niego ograniczeń myśli, sensu, znaczenia czy cielesności właśnie za pomocą tego, co Derrida nazywał absolutnym realizmem ${ }^{49}$.

Do podobnych wniosków doszła Morin, która twierdziła że:

Przez nazwanie Nancy'ego realizmu post-dekonstrukcyjnym „irredentyzmem” Derrida chciał podkreślić dwie rzeczy. Pierwsza, że w dotyku istnieje pewne pragnienie panowania albo asymilacji, które jest po drugiej stronie granicy, ponad którą albo na granicy której wydarza się dotyk. Po drugie, takie pragnienie asymilacji opiera się na przypuszczalnej homogeniczności. Tak ujmowaną kategorię dotyku Derrida traktował jako uczestnictwo w tym, co nazywał „metafizyką obecności” ${ }^{\circ 0}$.

Można jednak zadać pytanie, czy Nancy'ego post-dekonstrukcyjny realizm implikuje taki gest metafizyczny? Czy jest jednym z rodzajów metafizyki obecności? Odpowiedź Derridy jest ambiwalentna.

Tym, co można wywnioskować na podstawie rozważań Derridy, jest próba rozpoznania sposobu, w jaki Nancy’ego myślenie o dotyku zarówno przynależy do, jak i jednocześnie odróżnia się od tej metafizycznej, haptolocentrycznej tradycji. Z jednej strony Derrida jasno stwierdzał, że Nancy’ego figura dotyku zrywa z klasycznymi podejściami. Pisał tak: „Nancy, wydaje się, zrywa lub co najmniej dystansuje się wobec form metafizyki haptocentrycznej. Jego dyskurs o dotyku nie jest ani 
intuicjonistyczny, ani ujednolicony, ani homogeniczny, ani niepodzielny" ${ }^{51}$. To, co Nancy starał się skonceptualizować w pojęciu dotyku, to doświadczenie ucieleśnienia, które jest odmiennie interpretowane od tego wywodzącego się z przytaczanej tradycji metafizyki haptologicznej, jest „innym doświadczeniem ciała: odmienne ciało i odmienny corpus" ${ }^{2}$. Podobnie w odniesieniu do teologicznych źródeł tej kategorii myśl Nancy’ego można widzieć jako próbę pomyślenia cielesności ponad jej dziedzictwem chrześcijańskim, co autor Le Toucher nazywał dokonywaniem przez niego „dekonstrukcji chrześcijańskiego ciała” ${ }^{53}$. $\mathrm{Z}$ drugiej strony natomiast Derrida utrzymywał ambiwalencję, a nawet sceptycyzm wobec interpretacji figury dotyku autora Corpusu. Jeśli Nancy starał się skierować swoją koncepcję dotyku przeciwko tradycji haptologicznej uprzywilejowującej obecność, bezpośredniość, niepodzielność, to czynił tak na rzecz myślenia o ciele, w którym w jednym momencie ruchu dialektycznego zawiera się nie tylko, wedle Derridy, separacja czy dystans, ale także połączenie i styczność.

Dlatego dla Derridy, traktującego dotyk jako gest klasycznie dekonstrukcyjny, nieuchronnie pociąga on za sobą afirmację tego, co jednocześnie stara się przekroczyć, nawet jeśli Nancy ujmuje dotyk w terminach nieciągłości, fragmentaryzacji, podziału i dzielenia. Wynika to z tego, że rozumienie dotyku jako sfragmentaryzowanego lub nieciągłego może implikować takie jego rozumienie, które, w momencie samego jego przerywania, ostatecznie prowadzi do pewnej jedności i ciągłości. Podkreślał tę dwuznaczność Tomasz Załuski, pisząc że:

Nancy uprzywilejowuje figurę dotyku, gdyż pozwala mu ona stawić opór wszelkim postaciom transcendentalnego idealizmu i subiektywizmu. Dotyk staje się więc u Nancy'ego figurą ontologicznej relacji świata z samym sobą, sposobem na mówienie o świecie uwolnionym od „pozaświatowej” podmiotowości i pozostając jedynie w relacji do siebie. Chwaląc „post-dekonstrukcyjny realizm” Nancy'ego, Derrida

51 J. Derrida, Le Toucher. Jean-Luc Nancy, dz. cyt., s. 179-180.
52 Tamże, s. 247.
53 Tamże. 
zdaje się też jednak sugerować, że figura dotyku kryje w sobie tendencję asymilacjonistyczną i integracyjną, zagraża zawłaszczeniem, redukcją i niwelacją inności świata względem samego siebie, jego konstytutywnej nie-zbieżności, nie-styczności ze sobą. [...] Choć Nancy systematycznie podkreśla konstytutywny dla dotyku wymiar dystansu i przerwania, to w odczuciu Derridy „dotyk” wciąż zawiera w sobie nazbyt wiele z pragnienia bezpośredniości, immanencji, zawłaszczania i asymilacji tego, co dotykane ${ }^{54}$.

Jeśli tak jest, to Nancy'ego dystans wobec tradycji myśli haptocentrycznej jest, całkiem przeciwnie niż sam zamierzał, subtelną i złożoną wobec niej bliskością, choć być może na poziomie głębszym, bardziej fundamentalnym. Podobnie można rozumieć Nancy’ego „dekonstrukcję chrześcijaństwa” jako pogłębioną, choć krytyczną zarazem, przynależność do tego dziedzictwa. Tak właśnie twierdził Derrida, uważając, że Nancy’ego „dekonstrukcja chrześcijaństwa” „wydaje się być pewnym złożonym i paradoksalnym zadaniem, prawie niemożliwym i zawsze narażonym na bycie niczym innym jak chrześcijańską hiperbolą" ${ }^{55}$. Komentując ten wątek, Schrijvers zaznaczał, że dla Derridy

projekt Nancy’ego jest zarówno konieczny, jak i niemożliwy. Poprzez stwierdzenie, że dekonstrukcja chrześcijaństwa jest niemożliwa, Derrida [...] wskazywał fakt, że każda dekonstrukcja chrześcijaństwa może nam tylko przynieść więcej chrześcijaństwa, aczkolwiek w tej albo innej hiperbolicznej formie. Nancy natomiast odpowiadał na to jednoznacznie, że jeśli chrześcijaństwo nie jest niczym innym, niż tym, co otwiera świat na bezwarunkową inność albo alienację, to ta bezwarunkowość oznacza niedekonstruowalność, która poddaje się ruchowi dekonstrukcjii ${ }^{56}$.

Komentarz Derridy wydaje się zatem dwuznaczny, rozdarty, z jednej strony, pomiędzy dostrzeżeniem i podkreśleniem u Nancy’ego czegoś

54 T. Załuski, Dystans w relacji: Jacques Derrida i Jean-Luc Nancy, [w:] Foucault, Deleuze, Derrida, red. B. Banasiak, K. M. Jaksander, A. Kucner, Toruń 2011, s. 399-400.

55 J. Derrida, Le Toucher. Jean-Luc Nancy, dz. cyt., s. 249.

56 J. Schrijvers, What comes after christianity?..., dz. cyt., s. 275. 
zupełnie nowego - chodzi tu o ów absolutny realizm, który zrywa z tradycyjną logiką reprezentacji, z metafizyką obecności i chrześcijańską onto-teologią, a z drugiej strony - pojawiającym się w Le Toucher zarzutem, że jego refleksja na temat dotyku jest silnie wplątana w pojęcia, które sama starała się przemieścić i zdekonstruować.

Dlatego Derridy podkreślanie oryginalności i śmiałości Nancy’ego filozofii ciała konfrontowane jest z pewnymi zarzutami wobec niej, jak i ogólniejszym sceptycyzmem co do możliwości zbudowania takiej ontologii opartej na ciele. Łączy on entuzjazm dla refleksji Nancy'ego z wysuwaniem wobec jego myśli zastrzeżeń i wątpliwości. Jak już wskazywaliśmy, wiele argumentów Derridy przyjmuje formę dialogu również z innymi myślicielami, co można ujmować jako próbę ogólniejszego rozpoznania i zdekonstruowania znamiennych wyznaczników współczesnej, haptologicznej tradycji filozoficznej.

Natomiast tekst Noli me tangere można interpretować, jak pisał James $^{57}$, jako odpowiedź Nancy'ego daną Derridzie wobec jego uwag zawartych w Le Toucher. Nancy starał się wypracować taką koncepcję dotyku, która podkreśla jednoznacznie jego wymiar separujący, dynamizujący byty, do których dotyk się odnosi, na drugim planie pozostawiając jego wymiar zawłaszczający, homogenizujący ${ }^{58}$. W tym aspekcie dotyk przypomina pod pewnymi względami kategorię różni czy śladu u Derridy. Różnia ${ }^{59}$ to ruch odróżniania i odwlekania w czasie

57 I. James, The fragmentary demand..., dz. cyt., s. 141.

58 W tekście wprowadzającym do wystawy współczesnej sztuki japońskiej Nancy tak pisał o dotyku i cielesności: „Granice ciał są wyznaczane tylko przez boki, czyli przez ich wierzchnie strony, do których zaliczyć trzeba zarówno kończyny, jak też miejsca, linie oraz powierzchnie ich ekspozycji. Boki ocierają się o siebie - se côtoient, jak się mówi po francusku - to znaczy są tak blisko siebie, iż mogą się dotknąć, niemniej jednak zawsze jedno pozostaje na zewnątrz drugiego. Brzegi ciał, nasze boki, są tym, za sprawą czego dotykamy się i pozostajemy od siebie oddzieleni. Zbliżamy się i uciekamy przed sobą" ( J.-L. Nancy, Jedne obok drugich, tłum. M. Kwietniewska, [w:] Gendai: Wspótczesna sztuka Japonii - Pomiędzy Ciałem i Przestrzenią, Katalog wystawy w CSW Zamek Ujazdowski, Warszawa 2000, s. 10).

59 Neologizm „różnia” to jedno z najbardziej charakterystycznych pojęć filozofii dekonstrukcji Derridy. Zastąpienie litery „e” we francuskim słowie différence (różnica) literą $a$ (différance - różnia) miało podkreślać czysto graficzną odmienność pomiędzy tymi słowami, nieuchwytną na poziomie fonetycznym. Po pierwsze, filozof odwoływał się do jednego z dwóch podstawo- 
istniejących bytów. Podobnie jak w ciele Chrystusa, to, co istniejące, ma odsyłać do swojego przeciwieństwa, do nieobecności, do tego, co niewidzialne. Tak jak dotyk, różnia uwypukla, podkreśla istniejące różnice pomiędzy określonymi opozycjami metafizycznymi (jak na przykład ciało i dusza), dzięki owemu rozsunięciu, przerwie, nieciągłości zakodowanej w tej kategorii. I na koniec, różnia to sam ruch, który ma wykraczać poza opozycję czynności i bierności, sama będąc nieuchwytną, tak jak niedające się dotknąć ciało Chrystusa, jak sam dotyk. Dlatego w Noli me tangere Nancy pokazał, być może w najpełniejszy sposób, to, jak rozumie „dekonstrukcję chrześcijaństwa”, relację pomiędzy sensem a ciałem i duchem, odpowiadając jednocześnie i bezpośrednio na uwagi Derridy, na jego „sceptyczny czy rabiniczny dystans”60 wobec jego filozofii ciała.

Podsumowując, Nancy włożył wiele wysiłku, żeby odeprzeć takie ujęcie kategorii dotyku, które ma podkreślać relacyjność, modalność, a zarazem współ-istnienie tego, kto dotyka i tego, kto jest dotykany. Wydaje się, że dotyk posiada podobny charakter, co znamienna dla filozofii Nancy'ego kategoria partage, czyli zarazem udziału i podziału we wspólnej esencji ontologicznej. W tym sensie zapewnia separację, odrębność, autonomię, jak i udział, konieczną relację cielesnych egzystencji wobec siebie, ale bez zawłaszczania, gdyż jest to kontakt w dystansie. Tak rozumiany dotyk staje się jedną z podstawowych kategorii Nancy'ego ko-ontologii (podobnie jak pojęcia bycie-z, wspólnota, partager, ekspozycja i in.). A nawet, jak zaznaczała Małgorzata Kwietniewska, można jeszcze poważniej potraktować to pojęcie. Pisała ona tak:

wych znaczeń, stanowiącego semantyczny źródłosłów słowa różnica-różnia, mianowicie czasownika „różnić się". Différer to tyle co „odwlekać, odkładać na później, dokonać rozsunięcia zarówno w czasie, jak i w przestrzeni”. Rozsunięciu ma ulegać to, co obecne, to, co istniejące, dzięki czemu obecność odsyła także do swojego przeciwieństwa, do nieobecności, do tego, co niewidzialne. Po drugie, różnia odwołuje się do pierwotnego znaczenia czasownika différer, czyli różnić się w znaczeniu braku identyczności; być innym, możliwym do odróżnienia. Zob. J. Derrida, Różnia, tłum. J. Margański, [w:] tenże, Marginesy filozofii, Warszawa 2002, s. 29-56 oraz tenże, Pozycje, tłum. A. Dziadek, Katowice 2007, s. 11-13.

60 J.-L. Nancy, Noli me tangere, dz. cyt., s. 25-26, przypis 4. 
Dotyk staje się w ten sposób główną kategorią organizującą projekt filozoficzny Nancy’ego. Choć bez wątpienia wyrażenie „kategoria filozoficzna” jest tu nadużyciem. Dotyk bowiem nie daje się zaklasyfikować do żadnego rodzaju, typu, grupy pojęć filozoficznych i, podobnie jak sens, daje się określić jedynie przez owo „ku”, przez gotowość bycia-ku i bycia-dla innego ${ }^{61}$.

W tym sensie filozofia dotyku ma wymiar dekontrukcyjny, gdyż łączy w sobie wszystkie klasyczne strategie dekonstrukcji. Nancy, podobnie jak Derrida, od wewnątrz, z pozycji zaangażowanej, choć ambiwalentnej i zdystansowanej, dokonuje krytyki kategorii dotyku, a przy okazji samej cielesności, zdając sobie sprawę z własnego uwikłania w tę tradycję. Ale jest to również znamienna dla dekonstrukcji dialektyka nieusuwalnej (choć świadomej) przynależności do określonej tradycji myślenia, jak i dokonywanie wobec niej, na jej „obszarze” ciągłej inwencji. Nie wychodząc całkowicie poza dawne ramy pojęciowe, poza klasyczne ujęcia ciała, starał się Nancy tworzyć jednak coś zupełnie nowego. Jego dekonstrukcja cielesności jest filozoficzną inwencją świadomą własnych aporii. Pomyśleć niemożliwe, czyli dotyk jako jednoczesny kontakt i separacja, jako łączenie i oddzielanie - to dekonstrukcyjna treść koncepcji Nancy’ego (taka, jak kategorie daru, przebaczenia, gościnności czy sprawiedliwości u Derridy).

Zauważmy, że do tej pory ulubioną metaforą poznania większości filozofów był zmysł wzroku. Myśl niczym głębokie spojrzenie przenikała do istoty rzeczy. Tymczasem dotyk zatrzymuje się na granicy, dzięki czemu odczuwamy bycie sobą jako różnicę z innym, jako otwarcie-na, które jednak nie przeprowadza nas na drugą stronę. Jestem identyczny z sobą samym tylko na progu inności ${ }^{62}$.

Dla Nancy’ego dotyk nie jest gestem przywłaszczenia czy kontroli, lecz jest swoistą formą daności, jednak nie jednostronną, lecz taką,

${ }_{61}$ M. Kwietniewska, Między strukturalizmem a derridianizmem, czyli artystyczne uwikłania francuskiej filozofii pisma, „Sztuka i Filozofia”, 1996, nr 11, s. 142.

62 Tamże, s. 143. 
która zakłada wzajemność. Tym samym w żadnym razie nie może to być forma ontologicznej przemocy. Dotyk zawsze pozwala na ontologiczny dystans. Dotyk nie jest zjednoczeniem czy scaleniem, lecz bliskością, która nie niweluje odstępu pomiędzy ciałami, lecz zapewnia go.

Na koniec należy odnieść się do różnic w podkreślaniu roli filozofii chrześcijańskiej w samej dekonstrukcji. Nancy wyraźnie podkreślał fundamentalną rolę chrześcijaństwa w procesie dekonstrukcji filozofii zachodniej. Twierdził wręcz, że ona sama mogła dopiero się wykształcić $\mathrm{w}$ chrześcijaństwie, niejako wywodzi się z jego istoty. To bardzo odważna teza, z którą polemizował Derrida. W książce Le Toucher wyraźnie dystansował się wobec utożsamiania dekonstrukcji z chrześcijaństwem (jako demontażem, łączeniem i interpretacją źródeł greckich i żydowskich w filozofii Zachodu), przestrzegając przed próbą dechrystianizacji świata. W ten sam sposób, dość sceptycznie, traktował jedno z kluczowych pojęć filozofii Nancy’ego, którym jest dotyk, zarzucając tej kategorii zbyt bliskie powiązania $\mathrm{z}$ tradycją chrześcijańską, a także z kategorią immanencji. Przypomnijmy, że przez Nancy'ego dotyk ujmowany jako pojęcie ontologiczne, pozwalające na stworzenie swoistej relacji świata z samym sobą poza jakimikolwiek formami transcendentalizmu, jest takim rodzajem relacji, która unika jakiegokolwiek pozaświatowego bytu, czyli instancji zewnętrznej do opisu samego siebie. Ale zarazem nie zamyka się w swojej immanencji, lecz transcendentuje samo siebie, nie dochodząc do owej zewnętrznej transcendencji. Dlatego Nancy za pomocą dotyku, jako jednoczesnego dystansu i kontaktu, pisał o transimmanencji świata. Podobnie ma się rzecz z analizą egzystencji cielesnej, która dzięki dotykowi opiera się zarówno subiektywizmowi, jak i transcendentalizmowi. Dotyk nie jest bowiem zawłaszczeniem, pochłonięciem jednego ciała przez drugie, lecz przemieszczeniem się wzdłuż wzajemnej ekspozycji dwóch ciał, się-dotykaniem jako nieustającym przemieszczeniem siebie wobec innego. Gest dotykania, jako gest samego nakierowania-na, oddalony i bliski zarazem, gest zachowujący separację i łączność jednocześnie, to gest, będący sam w sobie dynamicznym wydarzeniem relacji, 
na którą otwierają się ciała, wystawiają się ku sobie, eksponują swoje zewnętrza oraz dystans pomiędzy nimi. To uprzywilejowanie kategorii dotyku w filozofii Nancy’ego podkreślał również Derrida, pisząc, że dotyk pozostaje dla Nancy'ego motywem ujmowanym jako rodzaj absolutnego realizmu, irredestycznego i post-dekonstrukcyjnego, ale nieredukowalnego do żadnej tradycyjnej formy realizmu. Czyli, z jednej strony, doceniał on wysiłek Nancy'ego, dostrzegał dekonstrukcyjny gest jego filozofii zawarty w tej kategorii, ale, z drugiej strony, wskazywał na asymilacjonistyczne i zbytnio immanentne tendencje w jego myśli. Innymi słowy, nawet jeśli Nancy podkreślał motyw separacji, przerwania czy dystansu zawarty w kategorii dotyku, to Derrida raczej uwypuklał w tym pojęciu rys bezpośredniości, styczności, immanencji czy zawłaszczenia. Dlatego pozostawał on sceptyczny wobec próby ucieczki Nancy'go od transcendentalno-podmiotowych struktur za pomocą figury dotyku.

\section{Bibliografia}

1. Alexandrova A., Devisch I., ten Kate L., van Rooden A. eds., Retreating Religion. Deconstructing Christianity with Jean-Luc Nancy, New York 2012.

2. Birnbaum A., To Exist is to exit the point, [w:] J.-L. Nancy, Corpus, tłum. R. A. Rand, New York 2008.

3. Derrida J., Le Toucher. Jean-Luc Nancy, Paris 2000.

4. Derrida J., Przemoc i metafizyka. Szkic na temat myśli Emanuela Lévinasa, tłum. K. Kłosiński, [w:] tenże, Pismo i różnica, Warszawa 2004.

5. Esposito R., Flesh and Body in the Deconstruction of Christianity, „Minnesota Review", 2010, no. 75, s. 89-99.

6. James I., The Fragmentary demand - an introduction to the philosophy of Jean-Luc Nancy, Stanford 2006.

7. ten Kate L., Intimate distance: rethinking the unthought God in Christianity. On Jean-Luc Nancy's Deconstruction of Christianity, Compared and Confronted with the 'Theological Turn in Phenomenology', „Sophia”, 2008, vol. 47 , issue 3, s. 327-343. 
8. ten Kate L., Outside in, inside out: Notes on the Retreating God in Nancy's Deconstruction of Christianity, ,Bijdragen. International Journal in Philosophy and Theology", 2008, vol. 69, no. 3, s. 305-320.

9. Kwietniewska M., Między strukturalizmem a derridianizmem, czyli artystyczne uwikłania francuskiej filozofii pisma, „Sztuka i Filozofia”, 1996, nr 11, s. 135-149.

10. Morin M.-E., Jean-Luc Nancy, London 2012.

11. Nancy J.-L., Corpus, tłum. M. Kwietniewska, Gdańsk 2002.

12. Nancy J.-L., L'Adoration (Déconstruction du christianisme, 2), Paris 2010.

13. Nancy J.-L., La déclosion (Déconstruction du christianisme, 1), Paris 2005.

14. Nancy J.-L., L'Extension de l'âme, Metz 2003.

15. Nancy J.-L., Noli me tangere, Paris 2003.

16. Nawrocki A., O projekcie Jean-Luc Nancy'ego „dekonstrukcji chrześcijaństwa”, „Kwartalnik Filozoficzny”, 2007, T. XXXV, s. 37-59.

17. Schrijvers J., What Comes after Christianity? Jean-Luc Nancy's Deconstruction of Christianity, „Research in Phenomenology”, 2009, no. 39, s. 266-291.

18. Watkin Ch., Neither/Nor: Jean-Luc Nancy's Deconstruction of Christianity, „Research in Phenomenology”, 2007, no. 37, s. 136-143.

19. Załuski T., Dystans w relacji: Jacques Derrida i Jean-Luc Nancy, [w:] Foucault, Deleuze, Derrida, red. B. Banasiak, K. M. Jaksander, A. Kucner, Toruń 2011. 